Selcuk Journal of Agriculture and Food Sciences

http://sjafs.selcuk.edu.tr/sjafs/index

Research Article
SJAFS

(2021) 35 (1), 33-38

e-ISSN: 2458-8377

DOI:10.15316/SJAFS.2020.225

\title{
Analysis of Opinions and Expectations of Farmers in Efeler District of Aydın Province on the Effects of Urbanization
}

\author{
(iDCansu BAŞARAN CANER ${ }^{1}$, (D) Sait ENGINDENIZ2* ${ }^{2 *}$
}

${ }^{1}$ Ege University, Faculty of Agriculture, Department of Agricultural Economics, Izmir, Turkey

${ }^{2}$ Ege University, Faculty of Agriculture, Department of Agricultural Economics, Izmir, Turkey

\begin{tabular}{l}
\hline ARTICLE INFO \\
\hline Article history: \\
Received date: 12.02 .2021 \\
Accepted date: 11.03 .2021 \\
\hline Edited by: \\
Zuhal KARAKAYACI; Selcuk Universi- \\
ty, Turkey
\end{tabular}

Keywords:

Urbanization

Land Use

Agricultural Land

Farmer Opinion and Expectation

\begin{abstract}
The aim of this study is to determine the opinions and expectations of the farmers on the effects of urbanization on agriculture in Efeler district of Aydin province. For this purpose, six of the villages that have gained the status of neighborhoods, which are around $10 \mathrm{~km}$ from the city center, have been selected for purpose. The data of the research was compiled by proportional sampling and survey method from 73 farmers. In the analysis of the research data, firstly the socio-economic characteristics of the farmers were examined and then the opinions and expectations of the farmers about the effects of urbanization on agriculture were revealed. Five-point Likert scale was used in the analysis of opinions and expectations. According to the results of the research, the average age of the farmers is 54.97 years and the average education period is 7.68 years. The average land size of the farmers is 73.01 decares and the average number of parcels is 3.42 . When the farmers are asked about the changes and expectations of urbanization; 68.49\% thought that their agricultural production was not affected at all, $91.78 \%$ thought that their agricultural income never changed, $80.82 \%$ thought that the agricultural land sales frequency increased, $95.89 \%$ thought that the agricultural land prices increased, $64.38 \%$ thought that urbanization could not prevent migration, $58.90 \%$ thought that urbanization may affect young farmers negatively. In Turkey, urbanization policies and other regulations should not adversely affect the agricultural structure and should be arranged in a way that does not exclude farmers from agriculture.
\end{abstract}

\section{Introduction}

Due to the rapid development of cities by fringing, the income generated in urban areas is higher than the yield of agricultural use and the risk is low, agricultural areas are rapidly transforming into urban uses, especially residential use. During the development of urban fringing, land existence in rural areas is considered as land stock (Sezgin and Varol, 2012). In the face of the sudden increases in the value of the agricultural lands around the settlement area, it becomes difficult to ensure that these lands continue to be used in agriculture (Paksoy and Direk, 1994).

In Turkey, after the Law No. 6360 date 06.12.2012 and published in Official Gazette No. 28489, 14 provincial has won metropolitan status, the metropolitan municipality has been extended to the boundaries of the province. It is foreseen that the Law No. 6360 can bring solutions to some urbanization and settlement problems in the center and districts of Aydin province. With this law, 17 districts of Aydın province became district municipalities affiliated to Aydın Metropolitan Municipality. The legal personality of village, town municipalities, subdistrict and subdistrict organizations within the administrative boundaries of these districts was abolished. In this framework, the legal personality of 490 villages, including 340 forest villages, 36 town municipalities were abolished and they became the neighborhoods of Aydın Metropolitan Municipality and district municipalities (Genç, 2014).

The urban development process, construction has increased both in the empty areas within the city in Aydın. The fertile agricultural areas around the İzmirAydın-Denizli Highway have turned into residential, industrial and commercial areas. The district center, town municipality and villages on this route have developed gradually by getting closer to the villages. Due to the lack of suitable areas in the city, some important facilities are located within the borders of neighboring municipalities and villages, and villages and municipalities close to the center are integrated with the city (Erdem et al.,1999; Deniz et al., 2005).

\footnotetext{
* Corresponding author email: basarancansu@gmail.com
} 
As the population in the cities increases, the area in which they spread expands and spreads to rural areas.As a result of urban development, natural areas of different types and sizes are transforming into cities (Türkten, 2015). Many studies have been conducted on the effects on agriculture and rural areas of urbanization in Turkey (Erbaş, 1989; Alhan, 1992; Aksoy and Özsoy, 2001; Çelik, 2007; Karataş, 2007; Sezgin, 2010; Sezgin and Varol, 2012; Karakayacı and Karakayac1, 2012; Akseki and Meşhur, 2013; Türkten, 2015; Uzun and Demir, 2016; Sağır and Yalçın, 2016; Partigöç, 2018; Tekçe, 2018). However, it is also necessary to closely follow the effects of urbanization on agriculture in different regions and to take necessary measures by determining the opinions of the farmers.

Efeler district of Aydin province is located on the fertile agricultural lands irrigated by the Büyük Menderes Plain. Aydın province's acquisition of metropolitan status and other regulations put into effect also affect the use of agricultural land and land markets in Efeler district. For this reason, there is a need for studies examining the effects of urbanization on agriculture in Efeler district. The purpose of this study is to determine the opinions and expectations of the farmers in the villages that gained neighborhood status in Aydın's Efeler district on the effects of urbanization on agriculture.

\section{Materials and Methods}

The main material of the study is the data compiled using a questionnaire method from the farmers in Efeler district of Aydin province. According to data for 2018 of Turkish Statistical Institute, the most densely populated district of Aydin province, with 287,518 people are added to the metropolitan municipality as the new district is the Efeler district (TurkStat, 2019).

There are 83 neighborhoods in Efeler district and 61 villages and towns have gained neighborhood status with the law numbered $6360.10 \%$ of 61 neighborhoods outside the urban area were included in the study, and six of the neighborhoods within $10 \mathrm{~km}$ of the city center were selected as purposeful. Accordingly, the neighborhoods of Çeştepe, Işıklı, Kadıköy, Kuyulu, Şevketiye and Tepecik were included in the study (Figure 1). According to the information obtained from the Efeler District Directorate of the Ministry of Agriculture and Forestry, there are a total of 298 farmers registered in the Farmer Registration System in the settlements included in the study. It was decided to include some of the farmers in the scope of the research by sampling method. For this purpose, the following proportional sample size formula was used (Newbold, 1995). This sampling method has been used in many previous studies (Tiryakioğlu and Artukoğlu, 2015; Özdemir et al., 2015; Ulu et al., 2016; Kızıloğlu and Kızılaslan, 2017; Bozdemir et al., 2019; Yüzbaşığlu, 2019; Barlas et al., 2019; Susam and Engindeniz, 2020; Değer et al., 2020).

$$
n=\frac{N p(1-p)}{(N-1) \sigma^{2} p x+p(1-p)}
$$

In the formula;

$n=$ Sample size

$N=$ Total number of farmers

$p=$ The proportion of farmers affected by urbanization (taken 0.5 to reach the maximum sample size)

$\sigma_{p x}^{2}=$ Variance.

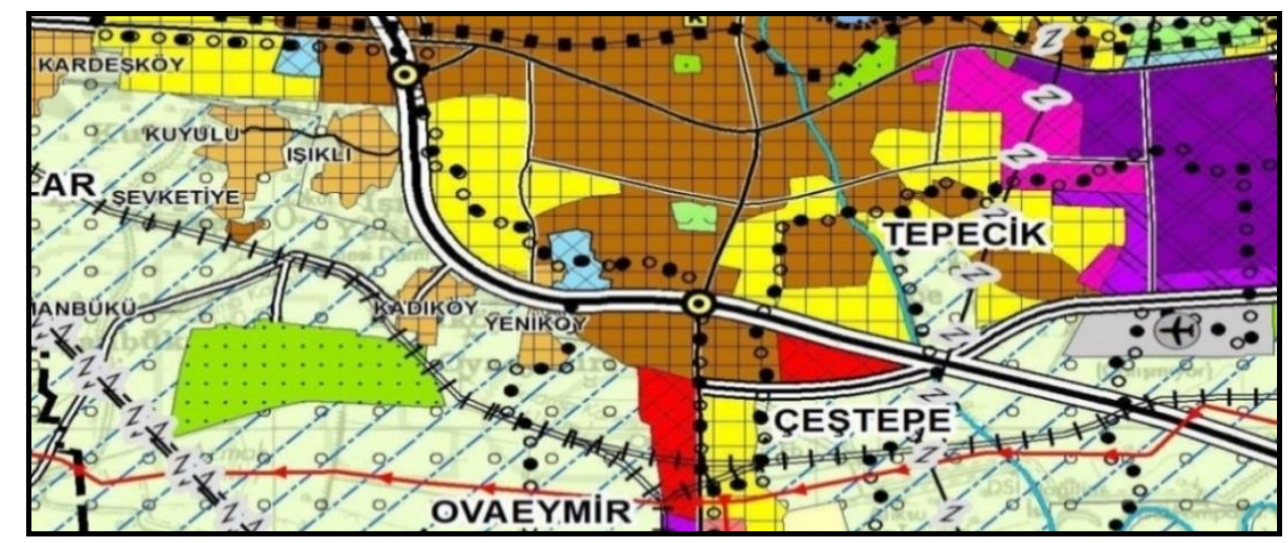

Figure 1. 1/100,000 scaled environmental plan of the research area.

\#Urban settlement area $\#$ Urban development area $\#$ Rural settlement area

Source: Ministry of Environment and Urbanization, 2018.

In the study, calculations were made based on $95 \%$ confidence interval and $10 \%$ margin of error, and the sample size was determined as 73 . In determining the number of farmers to be included in each neighborhood, the shares of the neighborhoods in the total number of farmers were taken as basis. The research data covers the year 2016.
In the analysis of the research data, first the socioeconomic characteristics of the farmers were examined, then the farmer's opinions and expectations about the effects of urbanization on agriculture were revealed. The five-point Likert scale was used in the analysis of opinions and expectations. 
In the conversion of the population in farms to the unit of male labor force; the coefficients of 0.50 for males and females in the 7-14 age group, 1.00 for males in the 15-49 age group, 0.75 for males in the 50 64 age group, 0.50 for females were based on (Aras, 1988).

\section{Results and Discussion}

The socio-economic characteristics of the farmers are given in Table 1. The age of the farmers varies between 24-76 and the average age is 54.97. The period of education varies between 5-16 years and the average period of education is 7.68 years. The average agricultural experience of the farmers is 24.59 years.

Table 1

Socio-economic characteristics of farmers

\begin{tabular}{lc}
\hline Age of farmers & 54.97 \\
Education period of farmers (year) & 7.68 \\
Agricultural experience of farmers (year) & 24.59 \\
Household size (person) & 3.33 \\
Family labor force potential (male work unit) & 1.95 \\
Land size (decare) & 73.01 \\
Equity ratio (\%) & 85.42 \\
Partner ratio in agricultural cooperative (\%) & 84.93 \\
\hline
\end{tabular}

The average household size in the farms is 3.33 and $50.45 \%$ of them are men. When examined by age; it is seen that $4.94 \%$ of the population is 0-6 years old, $9.47 \%$ is $7-14$ years old, $40.33 \%$ is $15-49$ years old, $28.81 \%$ is $50-64$ years old, $16.46 \%$ is 65 and older. Average family labor force potential in farms is 1.95 as a unit of male labor force and 585 as a male labor day.

Average land size of the farms is 73.01 decares. The average number of parcels is 3.42 and the average parcel size is 21.35 decares. When the land ownership status of the farmers is examined; according to the average of the farms, $76.63 \%$ of the lands in the farms are operated lands by the owner, $14.74 \%$ of the lands are rented land and $8.63 \%$ of the lands are operated lands by the partner. Cotton, wheat, corn, maize for silage and vetch are mostly produced on the farm lands. In addition, silage corn is also produced in the farms as the second product.

As the average of the farms, the total assets are 3.1 million Turkish Liras and $90.92 \%$ of them are land assets. When analyzed the distribution of assets according to the items; a large share of land assets $(83.88 \%)$, followed by tools and machinery $(6.91 \%)$ and buildings $(4.99 \%)$, respectively. However, $85.42 \%$ of the passive capital are equity capital. 62 of the 73 farmers included in the research are partners in at least one agricultural cooperative.

Within the scope of the research, the opinions of the farmers about the changes in their regions with the law numbered 6360 were examined. $93.15 \%$ of the farmers stated that there was no change in the legal structure of their land after their became a neighborhood (Table 2).

Table 2

The farmers' opinions on whether there is a legal change in their lands after their villages became neighborhood

\begin{tabular}{lcc}
\hline Answers & Number of farmers & $\%$ \\
\hline Yes & 5 & 6.85 \\
No & 68 & 93.15 \\
Total & 73 & 100.00 \\
\hline
\end{tabular}

$68.49 \%$ of the farmers stated that their agricultural production was not affected after their village became a neighborhood (Table 3).

Table 3

The farmers' opinions on whether their agricultural production is affected after their villages became neighborhood

\begin{tabular}{lcc}
\hline Answers & Number of farmers & $\%$ \\
\hline Positively affected & 6 & 8.22 \\
Negatively affected & 15 & 20.55 \\
Never affected & 50 & 68.49 \\
No idea & 2 & 2.74 \\
Total & 73 & 100.00 \\
\hline
\end{tabular}

$91.78 \%$ of the farmers stated that their agricultural incomes did not change after their villages became a neighborhood (Table 4).

Table 4

The farmers' opinions on whether their agricultural incomes have changed after their villages became neighborhood

\begin{tabular}{lcc}
\hline Answers & Number of farmers & $\%$ \\
\hline Increased & 1 & 1.37 \\
Decreased & 4 & 5.48 \\
Not changed & 67 & 91.78 \\
No idea & 1 & 1.37 \\
Total & 73 & 100.00 \\
\hline
\end{tabular}

In the study, when the opinions of the farmers about the indirect effects of their village being a neighborhood are examined; it has been determined that they agree with the statements "land demand and rents have increased" (4.05), "the land has become fragmented" (3.53). It was determined that they did not agree with the statements "marketing opportunities improved" (1.60), "irrigation opportunities improved" (1.74), "employment opportunities increased" (1.95), "public transport caused loss of productivity" (2.44), "transportation opportunities improved" (2.55), “environmental pollution occurred" (2.83) (Table 5). 
Table 5

The farmers' opinions on the indirect effects of their village being a neighborhood

\begin{tabular}{|c|c|c|c|c|c|c|c|c|c|c|c|}
\hline \multirow[t]{2}{*}{ Effects } & \multicolumn{2}{|c|}{$\begin{array}{c}\text { Strongly } \\
\text { disagree (1) }\end{array}$} & \multicolumn{2}{|c|}{$\begin{array}{c}\text { Disagree } \\
(2) \\
\end{array}$} & \multicolumn{2}{|c|}{$\begin{array}{c}\text { Undecided } \\
\text { (3) }\end{array}$} & \multicolumn{2}{|c|}{$\begin{array}{l}\text { Agree } \\
(4)\end{array}$} & \multicolumn{2}{|c|}{$\begin{array}{l}\text { Strongly } \\
\text { agree (5) }\end{array}$} & \multirow[t]{2}{*}{ Mean } \\
\hline & $\mathrm{n}$ & $\%$ & $\mathrm{n}$ & $\%$ & $\mathrm{n}$ & $\%$ & $\mathrm{n}$ & $\%$ & $\mathrm{n}$ & $\%$ & \\
\hline Irrigation opportunities improved & 34 & 46.6 & 29 & 39.7 & 5 & 6.8 & 5 & 6.8 & - & - & 1.74 \\
\hline Marketing opportunities improved & 39 & 53.4 & 27 & 37.0 & 4 & 5.5 & 3 & 4.1 & - & - & 1.60 \\
\hline Transportation opportunities improved & 29 & 39.7 & 12 & 16.4 & 3 & 4.1 & 21 & 28.8 & 8 & 11.0 & 2.55 \\
\hline Employment opportunities increased & 37 & 50.7 & 20 & 27.4 & 3 & 4.1 & 9 & 12.3 & 4 & 5.5 & 1.95 \\
\hline The land has become fragmented & 13 & 17.8 & 6 & 8.2 & 5 & 6.8 & 28 & 38.4 & 21 & 28.8 & 3.53 \\
\hline Land demand and rents have increased & 7 & 9.6 & 2 & 2.7 & - & - & 35 & 47.9 & 29 & 39.7 & 4.05 \\
\hline Environmental pollution occurred & 21 & 28.8 & 14 & 19.2 & 10 & 13.3 & 12 & 16.4 & 16 & 21.9 & 2.83 \\
\hline Public transport caused loss of productivity & 27 & 37.0 & 17 & 23.3 & 9 & 12.3 & 10 & 13.3 & 10 & 13.3 & 2.44 \\
\hline
\end{tabular}

When the opinions of the farmers about the change in the frequency of land sales after the village where they are located is a neighborhood; $80.82 \%$ of them stated that the frequency of sales increased, and $19.18 \%$ stated that the sales frequency did not change (Table 6).

Table 6

The farmers' opinions on the frequency of land sales after their villages became neighborhood

\begin{tabular}{lcc}
\hline Answers & Number of farmers & $\%$ \\
\hline Increased & 59 & 80.82 \\
Decreased & - & - \\
Not changed & 14 & 19.18 \\
Total & 73 & 100.00 \\
\hline
\end{tabular}

In the study, $95.89 \%$ of the farmers stated that the land prices increased after their villages became neighborhoods (Table 7).

Table 7

The farmers' opinions whether land prices have changed after their villages became neighborhood

\begin{tabular}{lcc}
\hline Answers & Number of farmers & $\%$ \\
\hline Increased & 70 & 95.89 \\
Decreased & - & - \\
Not changed & 3 & 4.11 \\
Total & 73 & 100.00 \\
\hline
\end{tabular}

Urban fringing may affect the agricultural lands and the purpose of use in the villages on one side, and on the other hand, it can also reduce the migration from rural to urban by solving infrastructure and transportation problems in these areas and increasing employment opportunities with industrialization. Farmers do not think that the migration in their region will decrease with urbanization $(64.38 \%$ ) (Table 8).
Table 8

The farmers' expectations as to whether urbanization will prevent migration in their region

\begin{tabular}{lcc}
\hline Answers & Number of farmers & $\%$ \\
\hline Yes & 24 & 32.88 \\
No & 47 & 64.38 \\
No idea & 2 & 2.74 \\
Total & 73 & 100.00 \\
\hline
\end{tabular}

In addition, farmers stated that urbanization would negatively affect young farmers $(58.90 \%)$ (Table 9$)$.

Table 9

The farmers' expectations as to whether urbanization will affect young farmers in their region

\begin{tabular}{lcc}
\hline Answers & Number of farmers & $\%$ \\
\hline Will positively affect & 10 & 13.70 \\
Will negatively affect & 43 & 58.90 \\
Will not affect & 16 & 21.92 \\
No idea & 4 & 5.48 \\
Total & 73 & 100.00 \\
\hline
\end{tabular}

Urbanization and the gradual expansion of the city center towards the surrounding settlements and villages cause the agricultural land to be used out of purpose. In the study, the farmers evaluate the spreading of the city center towards the villages as negative $(75.34 \%)$ in terms of land use. Farmers stated that the most common non-agricultural use of agricultural lands in the region is for residential construction $(89.87 \%)$, then for industry $(10.13 \%)$. On the other hand, $58.90 \%$ of the farmers stated that they would consider selling if their lands were parceled by the municipality, while $40.10 \%$ would not sell.

The effects of urbanization on agriculture and agricultural land have been determined in researches conducted in different regions. In a study conducted in Denizli, spatial, social, social and economic factors that cause urban sprawl and fringing were determined and it was determined that this negatively affected agricultural areas meadows, pastures and forests. 
In addition, the areas with the highest loss occurring in rural areas are determined as the areas around the main transportation connections and industrial areas (Patigöç, 2018). In a study conducted in Diyarbakır, it was determined that the urban area has grown more than five times. In addition, the city has expanded due to an annual average of 187 hectares of construction, and a large part of the urban development direction has moved towards I. and II. class agricultural lands (Özcanli et al., 2018). In a study conducted in Samsun, the spread of urban fringing to agricultural areas was examined by using satellite images. In the last 15 years, the urban settlement area has increased by $96.32 \%$ and has grown to approximately 3199 ha. It has been determined that the growth is generally towards the agricultural areas (Uzun and Demir, 2016). In a study conducted in Ankara, the effect of urban fringing on the misuse of agricultural land was examined. According to the results, the use of land in housing, industry and infrastructure investments in urban growth causes the misuse of agricultural lands (Sezgin, 2010). In a study conducted in Tokat, the effects of urbanization on land use were investigated. Especially fruit gardens were determined to be destroyed and it was determined that urbanization was possible without destroying the fertile lands. In a study conducted in Tokat, the effects of urbanization on land use were investigated. Especially fruit gardens were determined to be destroyed and it was determined that urbanization was possible without destroying the fertile lands. For this reason, it has come to the conclusion that in order to prevent the problem from reaching much more serious dimensions, the concerned parties should take measures to prohibit building on unproductive areas (Alhan, 1992).

\section{Conclusion}

Urbanization may affect the agricultural lands in the villages and their intended use on one side, and on the other hand, it can have a decreasing effect on migration from rural to urban by solving infrastructure and transportation problems in these areas and increasing employment opportunities with industrialization. However, according to the research results, the majority of the farmers believe that urbanization cannot prevent migration in the region.

The spreading of the city center towards the villages disrupts the integrity of the agricultural lands and creates fringing areas between the rural area and the city. As a matter of fact, the producers in the region stated that the spread of the city center towards the villages is negative in terms of land use. In these areas where urban sprawl has started, an effective land use policy should be established and necessary measures should be taken.

In the study, most of the farmers stated that the most common use of agricultural lands other than agriculture is housing construction and that they can sell their lands after urban fringing. In Turkey, urbanization policies and other regulations should not adversely affect the agricultural structure and should be arranged in a way that does not exclude farmers from agriculture. Only in this way will the optimum balance between natural resources and urban uses be achieved.

\section{References}

Akseki H, Meşhur MÇ, (2013). An analysis of the Konya's urbanized fertile agricultural lands and urban sprawl, Journal of Megaron 8: 165-174.

Aksoy E, Özsoy G, (2001). Determination of losses of agricultural lands by industry and urban settlement in Bursa city and its near environment by using GIS techniques, causes and solutions. GAP II. Agriculture Congress, 24-26 October 2001, Şanl1urfa, pp.1053-1060.

Alhan F (1992). Positive and negative effects of urbanization activities continued within the boundaries of Tokat central district on land use. Master Thesis, Institute of Science of Cumhuriyet University, Sivas.

Bozdemir M, Bayramoğlu Z, Ağızan K, Ağızan S (2019). Prudential expectation analysis in maize production. Turkish Journal of Agriculture-Food Science and Technology 7: 390-400.

Barlas S, Örmeci Kart, MÇ, Kınıklı F, Işın Ş (2019). Factors affecting the production decisions of cut flowers producers in Menderes Region of Izmir Province. Atatürk University Journal of the Agricutural Faculty 50: 231-238.

Çelik K (2007). Problems brought by the opening of agricultural lands to urban land development. Chamber of Survey and Cadastre Engineers, 11. Turkey Scientific and Technical Conference, 2-6 April 2007, Ankara.

Değer HC, Özder U, Kınıklı F, Yercan M (2020). Determining cooperative tendencies of tomato farmers on marketing in Muğla. Turkish Journal of Agricultural Economics 26(2):121-129.

Deniz B, Tunçay HE, Küçükerbaş EV (2005). Determination of the land use change pattern: the case of city of Aydin. Turkey, X. European Ecological Congress, 8 November 2005, KusadasiTurkey.

Erbaş MK (1989). Non-agricultural use of fertile rural lands in urbanization and industrialization process and the case of Bursa. Master Thesis, Institute of Science of Mimar Sinan Fine Arts University, Istanbul.

Erdem Ü, Nurlu E, Yilmaz R, Kahraman İM (1999). An investigation on Aydın province area use decisions based on the Büyük Menderes basin. 4th Agriculture and Environmental Problems Symposium, 9-10 September 1999, Söke-Izmir, pp.49-57. 
Genç N (2014). Law no. 6360 and effects on Aydın. Journal of Social Sciences Institute of Adnan Menderes University 1: 1-29.

Karakayacı Ö, Karakayacı Z (2012). Method proposal for determining urban/rural land value in urban sprawl area. The Journal of Academic Social Science Studies 5: 107-120.

Karataş N (2007). The effects of urban fringe trends in Izmir on the land ownership hand exchange process in Torbal1-Ayrancilar. Journal of Planning 40: 313.

Kızıloğlu R, Kızılaslan N (2017). Fertilizer use the condition of cultivator province center in Kahramanmaras. Turkish Journal of AgricultureFood Science and Technology 5: 18-23.

Ministry of Environment and Urbanization (2018). General directorate of spatial planning, AydinDenizli-Muğla planning region $1 / 100.000$ scale environmental plan. www.mpgm.csb.gov.tr (Access: 02.12.2018).

Newbold P (1995). Statistics for Business and Economics. Prentice-Hall, 773p. New Jersey, Pearson.

Özcanlı M, Özçağlar A, Özgen N, Benek S (2018). The effect of the spatial growth of Diyarbakir city area on agricultural land. The Journal of Academic Social Sciences 64: 479-506.

Özdemir B, Akbay C, Çelik A (2015). The current status and problems of apple growers in Gülnar District of Mersin City. Turkish Journal of Scientific Reviews 8: 56-58.

Paksoy M, Direk M (1994). Use of agricultural lands for non-agricultural purposes. Journal of Ecology 13:17-20.

Partigöç NS (2018). The spatial variation of rural settlements in the urbanization process: the case of Denizli city. Journal of Information Technologies 11: 89-98.

Sağır H, Yalçın E (2016). The role of the municipality in agricultural activities in the city after law no. 6360: the case of Konya Metropolitan Municipality. 10. Public Administration Symposium, 5-7 May 2016, pp.1109-1140.
Sezgin D (2010). The effect of urban fringing on the misuse of fertile agricultural soils: the case of Ankara. Master Thesis, Institute of Science of Gazi University, Ankara.

Sezgin D, Varol Ç (2012). The effects of urban growth and sprawl on the misuse of fertile agricultural lands in Ankara. METU Journal of the Faculty of Architecture 29: 273-288.

Susam Serez B, Engindeniz S (2020). The opinions and expectations of the farmers on socio-economic 1mpacts of Yortanlı Dam in Bergama District of Izmir Province. Selcuk Journal of Agriculture and Food Sciences 34: 118-123.

Tekçe Y (2018). The effect of Law No. 6360 on villages closed / new neighborhoods: the case of Aydin. Master Thesis, Institute of Social Sciences of Adnan Menderes University, Aydın.

Tiryakioğlu M, Artukoğlu MM (2015). A research on table olive production, marketing, problems and solutions: the case of Akhisar. Ege Journal of Agricultural Research 52: 131-139.

TurkStat (2019). Agricultural statistics and population statistics. http://www.tuik.gov.tr (Access: 16 May 2019).

Türkten H (2015). Investigation of the change in agricultural structure in the urban fringe area: the case of Atakum District of Samsun Province. Master Thesis, Institute of Science of Ondokuz Mayıs University, Samsun.

Ulu Ö, Engindeniz S, Özden A (2016). Analysis of input use efficiency in okra production in Izmir Province. Turkish Journal of Agricultural Economics 22(2):69-76.

Uzun A, Demir Y (2016). Determination of the expansion of urban sprawl to agricultural land through the use of satellite images; Samsun sample. Anatolian Journal of Agricultural Sciences 31: 408416.

Yüzbaşığlu R (2019). Tendencies of rural producer to soil analysis province center in Tokat. Journal of Bahri Dagdas Crop Research 8: 163-169. 